The Politics of Mental Health 
Critical Texts in Social Work and the

Welfare State

General Editor: Peter Leonard

Pete Alcock and Phil Harris

WELFARE LAW AND ORDER

Ragnhild Banton, Paul Clifford, Stephen Frosh, Julian

Lousada, Joanna Rosenthall

THE POLITICS OF MENTAL HEALTH

Steve Bolger, Paul Corrigan, Jan Docking, Nick Frost

TOWARDS SOCIALIST WELFARE WORK:

WORKING IN THE STATE

Paul Corrigan and Peter Leonard

SOCIAL WORK PRACTICE UNDER CAPITALISM:

A MARXIST APPROACH

Norman Ginsburg

GLASS, GAPITAL AND SOGIAL POLICY

Ian Gough

THE POLITIGAL EGONOMY OF THE WELFARE STATE

Chris Jones

STATE SOGIAL WORK AND THE WORKING GLASS

Peter Leonard

PERSONALITY AND IDEOLOGY: TOWARDS

A MATERIALIST UNDERSTANDING

OF THE INDIVIDUAL

Chris Phillipson

CAPITALISM AND THE CONSTRUCTION OF OLD AGE

\section{Forthcoming}

Lena Dominelli and Eileen McLeod

FEMINISM AND WELFARE: SOCIAL ACTION AND SOCIAL WORK

Paul Henderson and Pat Taylor

BEYOND VOLUNTARISM: VOLUNTARY WORK AND THE CRISIS OF THE

WELFARE STATE

Paul Joyce, Mike Hayes, Paıl Corrigan

SOCIAL WORKERS AND TRADE UNIONISM 


\title{
The Politics of Mental Health
}

\author{
Ragnhild Banton \\ Paul Clifford \\ Stephen Frosh \\ Julian Lousada \\ Joanna Rosenthall
}

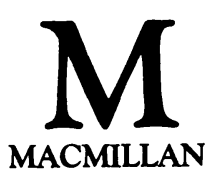


(C) Ragnhild Banton, Paul Clifford, Stephen Frosh, Julian Lousada and Joanna Rosenthall 1985

Softcover reprint of the hardcover 1st edition 1985

All rights reserved. No reproduction, copy or transmission of this publication may be made without written permission.

No paragraph of this publication may be reproduced, copied or transmitted save with written permission or in accordance with the provisions of the Copyright Act 1956 (as amended).

Any person who does any unauthorised act in relation to this publication may be liable to criminal prosecution and civil claims for damages.

First published 1985

Published by

Higher and Further Education Division

MACMILLAN PUBLISHERS LTD

Houndmills, Basingstoke, Hampshire RG21 2XS

and London

Companies and representatives

throughout the world

British Library Cataloguing in Publication Data

The Politics of mental health.-(Critical texts

in social work and the welfare state)

1. Mental illness--Treatment

I. Title II. Banton, Ragnhild III. Series

$616.89^{\prime} 06 \quad$ RC349.8

ISBN 978-0-333-36129-0

ISBN 978-1-349-17820-9 (eBook)

DOI $10.1007 / 978-1-349-17820-9$ 


\section{Contents}

About the Authors vii

Acknowledgements $\quad$ ix

Editor's Introduction $\quad \mathrm{x}$

Authors' Introduction 1

1 Politics and Power 7

Three practices $\quad 8$

Discourses and power $\quad 16$

Hospitals and doctors $\quad 19$

Power $\quad 35$

2 The Social Construction of the Individual 41

The individual 41

The construction of the individual 49

3 Mental Illness and Mental Health 57

Mental illness $\quad 57$

Social labelling $\quad 63$

Madness as sanity 66

$\begin{array}{ll}\text { Towards a politics of mental health } & 70\end{array}$

4 Therapy, Personal Change and Political Struggle 79

$\begin{array}{ll}\text { The illustrations } & 79\end{array}$

Therapy and personal change $\quad 80$

$\begin{array}{lr}\text { Therapy and struggle } & 107\end{array}$

5 Towards a Radical Therapeutic Practice 135

Challenging the dominant therapeutic discourse $\quad 136$

$\begin{array}{ll}\text { The acceptance of power } & 139\end{array}$ 
The refusal of power $\quad 142$

The purposes of therapy 145

Supervision, personal therapy and radical therapists 156

6 The Community Strategy 165

Fetishising the community 166

$\begin{array}{ll}\text { The penetration of community life } & 172\end{array}$

Knowledge and control 180

$\begin{array}{ll}\text { Resistance } & 182\end{array}$

$\begin{array}{ll}\text { Conclusion } & 191\end{array}$

References 197

Index 200 


\section{About the Authors}

This book has been written collectively. We began as a radical mental health group in the autumn of 1979, offering talks, courses and workshops to people living and working in the London boroughs of Lambeth and Southwark. In 1981 we formed a sub-group to concentrate on writing a pamphlet on mental health issues. As our ideas became more concrete and complex, this pamphlet changed into a book, although we retained the ideal of creating something together. Every part of the book was written collectively. The ideas were generated through discussion in the group, then one or two people wrote each section, which was then discussed and re-written, often by someone else. This process was a difficult one, with divisions appearing particularly between those members of the group who were reasonably confident about writing and those who found it intimidating and worrying. We tried hard to overcome these difficulties by discussion and argument and by making our regular group meetings a forum for support as well as for criticism.

All of us are professional mental health workers. Ragnhild works with ex-psychiatric patients in a Community Day Centre; Paul is a psychologist working with adults in the health service; Stephen is a psychologist working with children and families in the health service; Julian is a social work tutor offering counselling and consultancy services to community mental health groups; Jo is a social worker running groups and providing counselling within the Family Welfare Association. All of us are currently, or have been recently, in personal psychoanalysis or psychoanalytic psychotherapy, an experience that has had a substantial impact on the ideas expressed in the book. Our political commitments range from 
viii

ABOUT THE AUTHORS

membership of socialist parties to socialist feminist groups, but converge in our attempts to find ways to radicalise our professional practice. In doing this we have found important support from each other as we have wrestled with the concepts and implications of the book. 


\section{Acknowledgements}

Many people have helped us with this book, either directly or indirectly, through inspiring us to think and work in particular ways. We would especially like to thank the other members of the Lambeth and Southwark Community Mental Health Group. We are also indebted to Paul Hoggart and Sue Holland, members of the Battersea Action and Counselling Centre, which was the predecessor of the Lambeth and Southwark group. Peter Leonard's comments after our first draft were very significant in enabling us to pull our ideas together more cogently and in forcing us to do some political work which had been carefully avoided. Steven Kennedy's editorial comments have also been helpful at various points along the way.

Finally, we would like to thank Julian and Jo's housemates for putting up with our weekly meetings for so long, and Julian's mum for lending us her house for a weekend that turned out to be important in the life of the group.

Ragnhild Banton

Paul Clifford Stephen Frosh

Julian Lousada

Joanna Rosenthall 


\section{Editor's Introduction}

Central to a socialist conception of change is the notion of praxis: reflecting upon the world and changing it within the same process. 'If you want to know a certain thing', Mao Tsetung writes, ' 'you must personally participate in the struggle to change reality, to change that thing.' From a Marxist perspective, at least, the separation of theory from practice is a feature of the bourgeois social order which socialists must consistently struggle against. It follows from this notion of a human activity which unifies theory and practice that to create socialism involves 'subjective changes' in people as well as changes in 'objective' social relations, in production, reproduction, consumption, etc. 'In revolutionary activity', Marx and Engels write, 'the changing of oneself co-incides with the changing of circumstances.' The relationship between two kinds of changes - in people and in material relations - is not a simple matter of the one determining the other, but a more complex situation of interaction. It is a pity that this complexity is not better understood for it has far-reaching implications within the politics of the Left.

But to argue that people must change as part of a transformation of the entire social order is to direct our attention to precisely how people's consciousness, including our own, is constructed within historically specific social relations. It is clear, especially to those whose occupations involve responding to the inner distress produced by these social relations, that the social construction of the individual in terms of needs and desires is a matter of great complexity. The individual is not, after all, simply influenced by 'external' social forces, but constructs herself and is constructed within a set of social 
relations which define individuality itself. Moreover, it is evident that we are not conscious of the degree of penetration which the social order imposes upon us. Indeed, the orthodox Marxist position here ${ }^{3}$ is that this lack of awareness can only give way to a full understanding when the exploitive relationships characteristic of a class society are themselves swept away.

This problem of lack of awareness of precisely how we as individuals are socially constructed is especially significant in the field of mental health and mental illness. The dominant models of treatment are based upon an understanding of the individual as essentially prior to the social order rather than as being historically constructed within it: 'social factors' are seen as influencing the incidence and distribution of some mental illnesses, but the absence of a theoretical (and political) appreciation of the deeply embedded structural determinants of health and illness leads to a health care practice which remains fundamentally individualistic.

The significance of mental health as an arena of Left politics has developed steadily since the 1960s' interest in the social construction and control of deviance in general. The phenomenological and interactionist emphasis of workers in the mental health field in the 1960s onwards, of which R. D. Laing is perhaps the most famous, turned out to be too limited a basis for the revolutionary reappraisal of mental illness that was expected of it. Feminist approaches to women's mental health, with their focus on domestic and wage labour, and on the structural position of women generally in the genesis of mental illness, have proved to be a more important step forward. No progressive Left approach to mental health is conceivable today that does not attempt to take account of class, gender and ethnic relations as significant structural determinants.

But it is one thing to suggest what a Left theory and practice of mental health should aim to take account of and quite another matter to articulate in detail the very complex relationship between elements in the social order and mental states of individuals. More difficult still is to develop a practice on the basis of this understanding which is itself grounded in practice. There appear to be two alternative ways 
forward which present themselves to us here. First, we can attempt to develop an understanding of mental health on the exclusive theoretical and political base of socialist and feminist categories (class, labour, patriarchy, alienation, etc.) and reject any primary reliance on bourgeois psychology and psychiatry either as theory or practice. This involves creating a new psychology, an effort which is still in its infancy. Second, we can use (and possibly invert) bourgeois psychology and psychiatry for progressive, socialist and feminist ends, and in its deep commitment to psychoanalysis as a theory and a practice this book The Politics of Mental Health is representative of the second alternative.

In its emphasis on practice, The Politics of Mental Health is outstanding. A group of practitioners in the mental health field have successfully struggled together to create a coherent perspective on the contradictions and possibilities of a radical practice which deserves very wide and detailed attention. It is a book which bases itself upon a psychoanalytic account of individual development, understood within a generally Marxist perspective on ideology and material relations. A dynamic concept of the unconscious is crucial, the authors argue, to an understanding of the social construction of individuality for such a concept is essentially dialectic, surpassing in its explanatory power notions about the passivity of individuals in the face of the imprinting of socialisation process. It is on the basis of this socially informed psychoanalytic account that the major parts of this book are founded - the detailed examination and critique of the authors' own practice in mental health and parallel fields. The result is a courageous and eminently worthwhile exploration of possibilities, problems and contradictions in practice undertaken at a selfcritical level which compares most favourably with the radical rhetoric so frequently encountered. The authors are modest in their claims but are surely right in suggesting that their approach to mental health is essentially subversive.

There is no doubt that this book will raise many questions and debates amongst those on the Left who are committed to practice in the mental health field. It furthers some of the arguments entered into in Personality and Ideology: Towards a Materialist Understanding of the Individual, the book of mine 
which was published in this Critical Texts series in 1984. The two books differ in a number of ways: Personality and Ideology is essentially an introductory theoretical book, is more critical of psychoanalytic theory and places less emphasis on ideology and more on the actual material relations involved in labour processes. Both books are, however, similarly committed to the proposition that an understanding of, and response to, individual mental distress is an important part of the political agenda of the Left. The authors of The Politics of Mental Health mount, in my view, an overwhelmingly convincing case that mental health care is a significant arena of socialist, feminist and anti-racist practice - that it must not be vacated to the domination of bourgeois therapies, drug treatments and other methods of control and social legitimation.

This book calls on us to be profoundly self-critical of our own practice in a way which is deeply enriched by its psychoanalytic understandings. We have a responsibility to confront the challenge which the The Politics of Mental Health presents.

University of Warwick

Peter Leonard August 1984

\section{REFERENCES}

1. Mao Tsetung, 'On Practice' in Selected Readings from the Work of Mao Tsetung (Peking: Foreign Languages Press, 1971) p. 71.

2. K. Marx and F. Engels, The German Ideology, ed. C. J. Arthur (London: Lawrence \& Wishart, 1970) p. 95.

3. See L. Sève, Man in Marxist Theory and the Psychology of Personality (Brighton: Harvester Press, 1978). 